\title{
Arsenic Exposure and the Induction of Human Cancers
}

\author{
Victor D. Martinez, ${ }^{1,2}$ Emily A. Vucic, ${ }^{1}$ Daiana D. Becker-Santos, ${ }^{1}$ \\ Lionel Gil, ${ }^{2}$ and Wan L. Lam ${ }^{1}$ \\ ${ }^{1}$ Department of Integrative Oncology, British Columbia Cancer Research Centre, 675 West 10th Avenue, \\ Vancouver, BC, Canada V5Z 1 L3 \\ ${ }^{2}$ Biomedical Sciences Institute, Faculty of Medicine, University of Chile, Independencia 1027, 8380453 Santiago, Chile
}

Correspondence should be addressed to Victor D. Martinez, vmartinez@bccrc.ca

Received 1 May 2011; Revised 25 August 2011; Accepted 25 August 2011

Academic Editor: David O. Carpenter

Copyright (C) 2011 Victor D. Martinez et al. This is an open access article distributed under the Creative Commons Attribution License, which permits unrestricted use, distribution, and reproduction in any medium, provided the original work is properly cited.

\begin{abstract}
Arsenic is a metalloid, that is, considered to be a human carcinogen. Millions of individuals worldwide are chronically exposed through drinking water, with consequences ranging from acute toxicities to development of malignancies, such as skin and lung cancer. Despite well-known arsenic-related health effects, the molecular mechanisms involved are not fully understood; however, the arsenic biotransformation process, which includes methylation changes, is thought to play a key role. This paper explores the relationship of arsenic exposure with cancer development and summarizes current knowledge of the potential mechanisms that may contribute to the neoplastic processes observed in arsenic exposed human populations.
\end{abstract}

\section{Introduction}

Arsenic (As) is a chemical element classified as a metalloid. The most common oxidation states in the environment are +3 (As ${ }^{\mathrm{III}}$, also known as arsenite) and +5 ( $\mathrm{As}^{\mathrm{V}}$ or arsenate), which exhibit different grades of toxicity [1]. Arsenic compounds can be found in organic (when linked with carbon and hydrogen) and inorganic (when combined with oxygen, chlorine, and sulfur, among other elements) forms [2].

Long term ingestion of inorganic arsenic has been associated with several human diseases. There are various sources of ingested arsenic, such as food (mainly in fish and seafood, algae, and cereals), air (coal-fired power generation and smelting), and water [3]. Of the various sources of arsenic in the environment, long-term exposure of arsenic in drinking water likely poses the greatest threat to human health [4]. Given its daily and widespread consumption, occurrence of arsenic in drinking water has been increasingly recognized as a major public health concern in several regions of the world over the past decades [5-7]. In fact, groundwater used for drinking contaminated with naturally occurring inorganic arsenic in Bangladesh represents one of the largest mass poisoning of a population in history [8]. Worldwide, an estimated 160 million people live in regions with naturally elevated levels of arsenic in drinking water, due to the presence of arsenic-rich geological formations [7].

Arsenic is a natural component of rocks containing copper or lead, which can result in release of arsenic into water or air in zones of intensive mining activities [6]. Due to these geological conditions and/or anthropogenic activities, soil and water supplies in these areas contain high concentrations of arsenical compounds [9]. This situation is compounded in extremely arid zones (such as in Northern Chile), where water sources are scarce and contaminated water serves as a drinking and irrigation supply. This can lead to massive chronic poisoning-called arsenicosis—affecting local populations [10]. Arsenic-contaminated drinking water represents an important public health issue, especially for developing countries.

Due to its physical characteristics (no odor, no color, and no flavor), arsenic exposure is often unnoticed, especially when ingested through drinking water. In this context, long-term effects are a major health concern in affected areas. The World Health Organization (WHO) and the U.S. Environmental Protection Agency have recommended a threshold of $10 \mu \mathrm{g} / \mathrm{L}$ for inorganic arsenic concentration in drinking water $[11,12]$. Unfortunately, millions of people are exposed to toxic levels and are at increased risk for 
the adverse health effects of arsenic $[6,13]$. Concentrations exceeding this threshold have been described in Bangladesh, India, China, Argentina, Mexico, Canada, USA, and Chile, among other countries [14].

There is a strong body of evidence linking arsenic with a variety of health problems, from acute toxicities to chronic diseases which can take years to develop. Arsenic-related diseases include skin lesions, hypertension, ischemia, some endemic peripheral vascular disorders (e.g., "black foot disease"), diabetes, severe arteriosclerosis, neuropathies, and, significantly, many types of cancer [15-18]. Cancer-death risk associated with daily consumption of 1.6 liters of water with inorganic arsenic $(50 \mu \mathrm{g} / \mathrm{L})$ has been estimated to be 21/1,000 [19].

Arsenic has been classified as a class I human carcinogen by the International Agency of Research on Cancer (IARC), meaning that there is sufficient evidence of carcinogenicity to humans. Despite evidence in humans, animal models fail to replicate these observed effects, hampering elucidation of the exact mode(s) of action underlying arsenic related carcinogenicity [20]. Skin and several types of internal cancers, including bladder, kidney, liver, prostate, and lung have been associated with arsenic ingestion [10,21-25]. Skin cancer is the most common form of neoplasm associated with arsenic ingestion, while lung cancer corresponds to the most deadly $[13,26]$. Interestingly, arsenic (specifically arsenic trioxide or $\mathrm{As}_{2} \mathrm{O}_{3}$ ) has been used as a chemotherapeutic agent for several types of cancer, with some studies showing high percentage of response in patients with acute promyelocytic leukemia (APL) $[27,28]$. We will also discuss this issue in further sections.

\section{Common Arsenic-Induced Malignancies}

2.1. Skin Cancer. The relationship between arsenic and skin cancer has been well documented over the past several decades $[29,30]$. The first inferences were made through observations of an increased frequency of skin cancer cases following treatment with Fowler's solution (1\% potassium arsenite), formerly used for a variety of skin and hematological disorders [31]. Bowen's disease (intraepithelial carcinoma or carcinoma in situ), basal cell carcinoma (BCC)- and squamous cell carcinoma ( $\mathrm{SqCC}$ ) are the most common malignancies found in patients with long-term exposure to arsenic. Merkel cell carcinoma, an uncommon and highly aggressive cutaneous neoplasm, has been also documented at a lower frequency [32-35].

Arsenic-related skin SqCC can develop either de novo or progress from Bowen's disease, whereas arsenic-related BCC develops usually in multiple foci and areas of the body covered from sun exposure, in contrast to cases originating from other skin carcinogens, such as UV-light [36-38]. Arsenic-related Bowen's disease can appear 10 years after arsenic exposure, while other types of skin cancer can have a latency period of 20 or 30 years [39]. A dose-response relationship and cell-type specificity have been described for arsenic-related skin cancer [40, 41]. Additionally, normal human epidermal keratinocytes exposed to varying noncytotoxic/slightly cytotoxic concentrations of inorganic arsenic exhibit gene expression changes associated with molecular pathways relevant to arsenic-related skin carcinogenesis, such as oxidative stress, increased transcriptional levels of keratinocyte growth factors, and modulation of MAPK and NF- $\kappa$ B pathways [42].

Premalignant skin lesions are relatively early manifestations of arsenic toxicity and are often considered precursors to arsenic-induced skin BCC and SqCC tumors [43]. These lesions include dermal manifestations such hyperpigmentation (a finely freckled, "raindrop" pattern of pigmentation or depigmentation) and hyperkeratosis (skin thickening, mainly at palms and the feet). These lesions are commonly found in chronically exposed populations and are considered a diagnostic criterion of arsenicosis [44]. Moreover, some genetic susceptibilities to these arsenic-related skin lesions have been proposed, since they do not occur in every exposed individual [45]. Hyperkeratosis can appear with shorter periods of arsenic exposure, and it has been described that these lesions give rise to the majority of arsenic-induced skin cancer $[46,47]$. Additionally, it has been demonstrated that a significant proportion of fatal cases of skin cancer occurred in patients with prior signs of arsenicosis, such as keratosis and hyperpigmentation [31, 48].

In addition to directly affecting the carcinogenic process, it has been demonstrated that arsenic toxicity can also be potentiated by other environmental carcinogens. For example, arsenic-exposed individuals with a history of smoking and chronic exposure to environments with high fertilizer use may be more susceptible to cancer-prone skin lesions than those without these risk factors, even at the same level of arsenic exposure [43]. Arsenic can act as a cocarcinogen with UV light in a synergistic mode of action, leading to development of hyperkeratosis $[49,50]$. Additionally, the same mode of action was observed between high levels of arsenic (over $100 \mu \mathrm{g} / \mathrm{L}$ ) and tobacco smoking with respect to risk of skin lesions in men [51].

2.2. Lung Cancer. There exists a significant dose-response relationship between arsenic concentration in water and incidence of lung cancer and other malignancies for both men and women [52]. The association between lung cancer and ingested arsenic was discovered following therapeutic application of this metalloid in psoriasis patients treated with Fowler's solution [53-55]. Thereafter, an increased lung cancer risk following exposure to arsenic in drinking water was demonstrated by several case-control and cohort-type studies [20]. Consistent, positive, and statistically significant associations among individuals exposed to high concentrations of arsenic in drinking water and increased risk of lung cancer have been detected [56, 57]. Based on large epidemiology studies in 1999, a report from the National Research Council (NRC, USA) concluded that there was sufficient evidence suggesting that the ingestion of arsenic in drinking water causes lung cancer, among other types of malignant neoplasias [58]. After this publication, other major arsenic and lung cancer epidemiological studies were published $[25,59]$. Due to mounting evidence, the NRC 
study was reevaluated in 2001, concluding that the carcinogenic effects of arsenic in humans are significant, and that lung (and bladder) cancer should continue to be the focus of arsenic risk assessment for regulatory decision making [60].

Interestingly, the increase risk of lung cancer associated with arsenic seems to be cancer subtype specific. For example, where SqCC incidence had decreased worldwide and overwhelmingly associated with cigarette smoking; in Northern Chile, a high proportion of SqCC frequently occurs in never smokers who have been chronically exposed to arsenic $[25,61]$.

As mentioned, Bangladesh represents the largest mass poisoning of a population in history, as groundwater used for drinking is contaminated with naturally occurring inorganic arsenic [8]. In rural areas in Bangladesh, arsenic contamination in drinking water from tube wells is associated with lung cancer in males, with lung SqCC being the predominant histological subtype in areas with arsenic concentrations above $100 \mu \mathrm{g} / \mathrm{L}$ [62]. In these areas, the lifetime mortality risks of lung cancer are 159.1/100 000 for males and 23.1 for females (per 100000 population) [63].

Blackfoot disease (BFD) is an endemic, peripheral arterial disease characterized by severe systemic arteriosclerosis and spontaneous gangrene resulting in amputation, common to individuals exposed to arsenic in Southwestern Taiwan [18]. In zones affected by BFD, increased incidence and subsequent mortality rates for lung cancer have been demonstrated, especially among those who used arseniccontaminated well water for $\geq 40$ years [64]. Smokers in this area have a 4.1-fold higher relative risk for lung cancer, suggesting a possible synergistic relationship between arsenic and tobacco exposures in terms of lung tumorigenesis [65]. Also, short-term exposure ( 5 years) of arsenic-contaminated drinking water $(\geq 0.05 \mu \mathrm{g} / \mathrm{L})$ can also result in elevated lung cancer risk [66].

The Andean zone in South America is another area where the relationship between chronic arsenic exposure and lung cancer has been demonstrated. A dose-response relationship between arsenic in drinking water and lung cancer was found in central regions of Argentina [67], where arsenic concentrations in water supplies were $>100 \mu \mathrm{g} / \mathrm{L}$, even reaching as high as $2000 \mu \mathrm{g} / \mathrm{L}$ [68]. A correlation between increased arsenic concentration in drinking water and lung cancer incidence was also discovered in Northern Chile [25]. In this area, lung cancer mortality increased ten years after the initiation of high-level exposure (arsenic concentration $>90 \mu \mathrm{g} / \mathrm{L}$ in 1958) [10].

Chronic exposures to water contaminated with low concentrations of arsenic do not, however, show the same strong associations with increased cancer incidence and mortality. For example, a study carried out in Denmark [69] did not find any significant association between exposure to low concentrations of arsenic in drinking water $(0.05-$ $25.3 \mu \mathrm{g} / \mathrm{L}$ ) and risk of melanoma or lung cancer, among other types of neoplasias. Similarly, another study conducted in Belgium did not find a significant correlation between exposure to drinking water containing relatively low arsenic concentrations $(20-50 \mu \mathrm{g} / \mathrm{L})$ and lung cancer mortality [70].
Genetic factors are thought to modulate susceptibility to arsenic-induced lung cancer. Carriers of CYP1A1* 2A/GSTM1 homozygous deletion genotype show increased odds ratios for lung cancer, especially among smokers [71, 72]. In addition, our group has recently proposed that genomic aberrations in arsenic induced lung cancers exhibit distinct molecular characteristics. Using a whole genome tiling-path comparative genomic hybridization (CGH) array platform (described in [73]), we analyzed DNA copynumber alterations (CNAs) among lung SqCC cases from a Northern Chilean population chronically exposed to inorganic arsenic in drinking water (Figure 1) [74]. We identified unique patterns of chromosomal disruption and gene dosage related to SqCC from never smokers in Northern Chile, which did not correlate with normal DNA copy-number variations (Figure 1). This has led to the growing hypothesis that lung SqCC in arsenic-exposed individuals could represent a molecularly distinct form of this disease [74].

\section{Carcinogenic Mechanisms of Arsenic Exposure}

3.1. Arsenic Biotransformation as a Toxicity Activation Mechanism. Arsenic metabolism implicates a series of reduction and oxidation reactions. Pentavalent arsenical species are reduced to trivalent species, and oxidative methylation occurs to yield methylated tri- and pentavalent metabolites [75]. However, more than a detoxification mechanism, it has been proposed that methylation can activate the toxic and carcinogenic potential of arsenic, since it has been demonstrated that mono/dimethylated arsenical species (both tri/pentavalent) can affect gene transcription, and are more potent enzyme inhibitors and cytotoxins than nonmethylated species [76, 77]. Moreover, since the arsenic biotransformation pathway uses S-adenosylmethionine (SAM) as a methyl group donor, arsenic can also interfere with a number of cellular processes that require methyl groups, leading to the idea that alteration of epigenetic mechanisms can also participate in arsenic-induced carcinogenesis [78]. A variety of these arsenic associated toxic events have been elucidated in cell line and animal models (Table 1).

After reduction of $\mathrm{As}^{\mathrm{V}}$ to $\mathrm{As}{ }^{\mathrm{III}}$ by purine nucleoside phosphorylase, $A s^{\mathrm{III}}$ is methylated via a As ${ }^{\mathrm{III}}$-methyltransferase, using SAM as a methyl group donor [79], producing mono and dimethylated trivalent species, such as monomethylarsonous acid $\left(\mathrm{MMA}^{\mathrm{III}}\right)$, dimethylarsinous acid $\left(\mathrm{DMA}^{\mathrm{III}}\right)$, and equivalent pentavalent species (monomethylarsonic acid or $\mathrm{MMA}^{\mathrm{V}}$, and dimethylarsinic acid or $\mathrm{DMA}^{\mathrm{V}}$. Interestingly, there is little evidence of methylated arsenic metabolites in skin, and in vitro studies have demonstrated that keratinocytes display very slow rates of arsenic methylation, and only mono-methylated species are produced $[45,80]$. It has been proposed that $A s^{I I I}$ could be one of the responsible agents in arsenic related skin carcinogenicity, since it acts as a cocarcinogenic to mouse skin [81]. Additionally, individuals with arsenic-related skin lesions or skin cancer exhibit lower levels of dimethylated species in urine (in contrast to monomethylated species) [82-85], indicating that a lower 


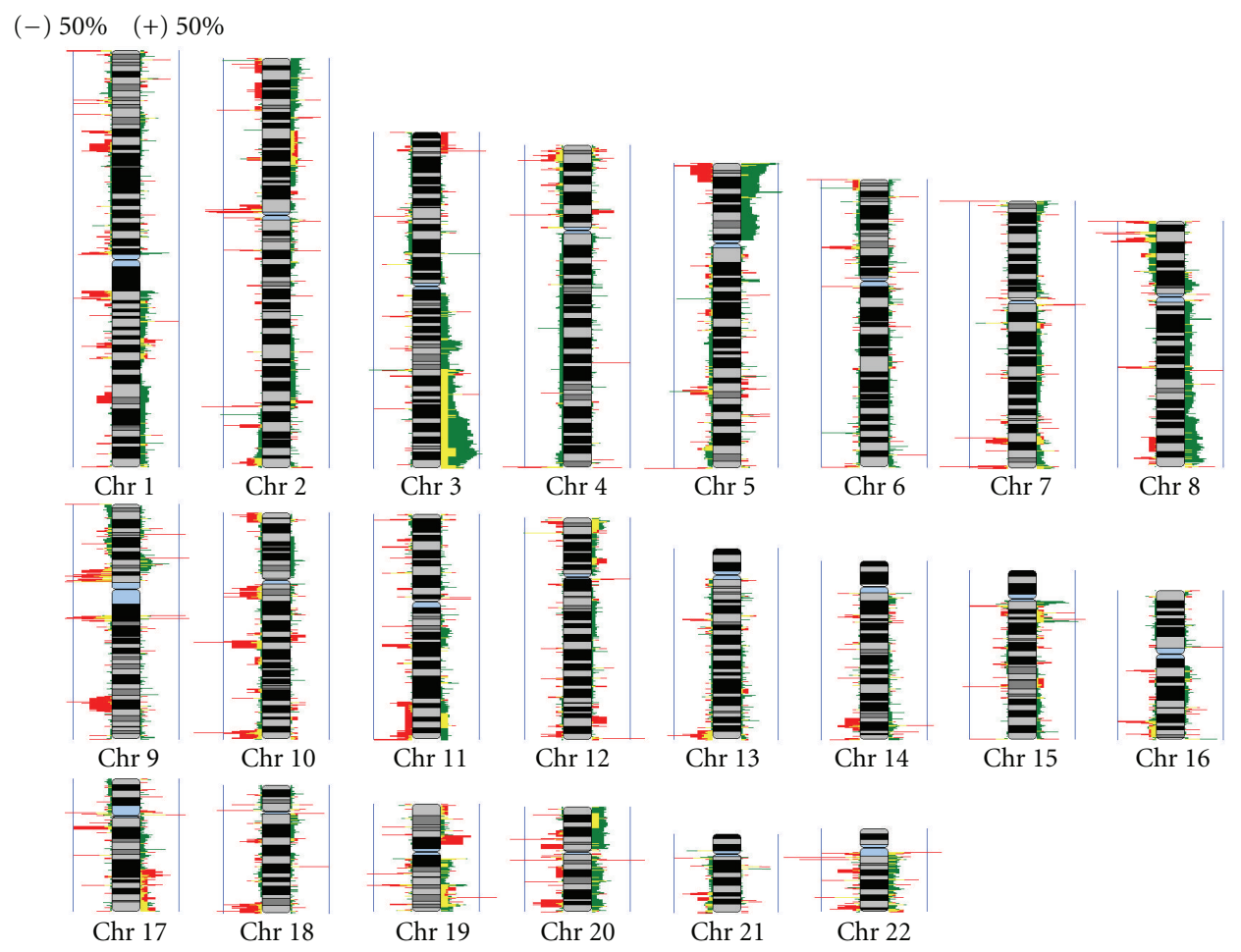

(a)

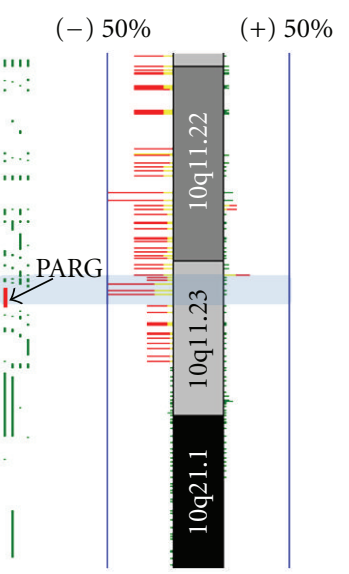

(b)

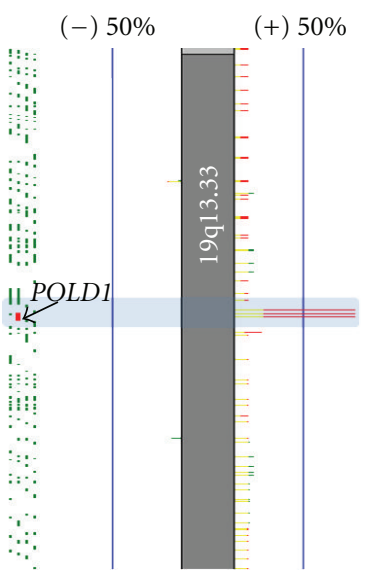

(c)

FIGURE 1: Genome-wide identification of arsenic-related and smoking independent DNA copy number alterations in lung squamous cell carcinoma (SqCC). Genomic copy number profiles for lung SqCC biopsies $(n=52)$ were obtained using whole genome aCGH. SqCC tumors from smokers $(n=42)$, comprised $(n=30)$ samples from North American with no known arsenic exposure, and $(n=12)$ samples from Northern Chile from individuals chronically exposed to arsenic. SqCC tumors from never smokers $(n=10)$ were from chronically arsenicexposed individuals from Northern Chile. (a) Frequency plot of arsenic-related and smoking independent copy number differences in SqCC. The frequency of DNA gain/loss for each probe was calculated and plotted for each group, where smokers (dark green) and never smokers (red). Regions exhibiting similar alteration in both groups are denoted in yellow. The magnitude of green and red bars represents percent alteration for each probe per group (0-100\%, with blue vertical lines representing $50 \%$ frequency). DNA gains and losses are represented to the right and left of each chromosome, respectively. Analysis was restricted to autosomes, with any differences based on sex subtracted from further analysis. A high frequency of copy number alteration, previously undescribed for SqCC were evident in arsenic exposed tumors from never smokers, particularly for chromosome 3q. (b) Detail of DNA losses at 10q11.23 specific to never smokers are highlighted in a light-blue rectangle. PARG, previously shown to mediate cell death in response to genotoxic stimuli (PMID: 19571039), is indicated in red. (c) Recurrent DNA gain found in never smokers at 19q13.33. This segment contains the POLD1 gene, a DNA polymerase delta complex, involved in DNA replication and repair (red probe). 
TABLE 1: Changes in functions associated to arsenic-related carcinogenicity.

\begin{tabular}{|c|c|c|c|}
\hline Type of alteration & Cell model/type & As species & Reference \\
\hline \multicolumn{4}{|l|}{ Associated to oxidative stress } \\
\hline DNA strand break & $\begin{array}{l}\text { Human fetal lung fibroblast ( } 2 \text { BS } \\
\text { cells) }\end{array}$ & $\mathrm{As}^{\mathrm{III}}$ & {$[121]$} \\
\hline DNA strand break & $\begin{array}{l}\text { Human alveolar epithelial type II } \\
\text { (L-132) cells }\end{array}$ & $\mathrm{DMA}^{\mathrm{V}}$ & {$[122]$} \\
\hline $\begin{array}{l}\text { Single-strand DNA breaks, DNA-protein adducts, sister } \\
\text { chromatid exchanges }\end{array}$ & Human fibroblast cell lines & $\mathrm{As}^{\mathrm{III}}$ & {$[123]$} \\
\hline Formation of apurinic/apyrimidinic sites & $\begin{array}{l}\text { Human alveolar epithelial cell } \\
\text { line (L-132) }\end{array}$ & DMA & {$[124]$} \\
\hline Induction of 8-OHdG & $\begin{array}{l}\text { Human breast cancer MCF-7 } \\
\text { adenocarcinoma epithelial cells }\end{array}$ & $\mathrm{As}^{\mathrm{III}}$ & {$[125]$} \\
\hline Increases 8-oxo-G levels through $(\mathrm{CH} 3)_{2} \mathrm{AsOO}$ & & $\mathrm{DMA}^{\mathrm{V}}$ & {$[126,127]$} \\
\hline $\begin{array}{l}\text { Presence markers for oxidative stress were detected, } \\
\text { including 8-oxodG }\end{array}$ & Mouse bronchiolar Clara cells & $\mathrm{DMA}^{\mathrm{V}}$ & {$[128]$} \\
\hline Double-strand DNA breaks & Mammalian cells & & {$[96]$} \\
\hline \multicolumn{4}{|l|}{$\begin{array}{l}\text { Epigenetic changes in DNA methylation/histones } \\
\text { modification/miRNA expression }\end{array}$} \\
\hline Alteration of methylation in p53 promoter & A549 cell line & $\begin{array}{l}\mathrm{As}^{\mathrm{III}} \\
\mathrm{As}^{\mathrm{V}}\end{array}$ & {$[106]$} \\
\hline $\begin{array}{l}\text { Inductor of hypermethylation of the p16INK4a and } \\
\text { RASSF1A CpG islands in nontumor lung tissues (including } \\
\text { hyperplasia and adenoma) and lung adenocarcinomas }\end{array}$ & $\begin{array}{l}\text { Lungs of mice exposed during } 18 \\
\text { months }\end{array}$ & $\mathrm{As}^{\mathrm{V}}$ & {$[107]$} \\
\hline Increase of dimethylated $\mathrm{H} 3 \mathrm{~K} 9$ & Human BEAS-2B cell line & $A s^{I I I}$ & {$[112]$} \\
\hline $\begin{array}{l}\text { Increased H3K9 dimethylation and decreased H3K27 } \\
\text { tri-methylation (gene silencing), increasing H3K4 } \\
\text { tri-methylation (gene-activating mark), increases histone } \\
\text { methyltransferase G9a protein levels }\end{array}$ & Human A549 cell line & $A s^{I I I}$ & {$[112]$} \\
\hline $\begin{array}{l}\text { Changes to histone } \mathrm{H} 3 \text { acetylation, DNA promoter } \\
\text { methylation, and decreases expression of the DBC1, } \\
\text { FAM83A, ZSCAN12, and C1QTNF6 genes }\end{array}$ & $\begin{array}{l}\text { Human nontumorogenic cell } \\
\text { lines }\end{array}$ & & {$[113]$} \\
\hline Altered expression of hsa-miR-210, $-22,-34 a,-221$, and -222 & Human lymphoblastoid cells & $\mathrm{As}^{\mathrm{III}}$ & {$[116]$} \\
\hline Reduction in levels of miR-200 & $\begin{array}{l}\text { Immortalized p53-knocked } \\
\text { down human bronchial epithelial } \\
\text { cells (HBECs) }\end{array}$ & $A s^{I I I}$ & {$[117]$} \\
\hline Decrease in expression of miRNA-9, $-181 b,-124$, and $-125 b$ & Chick embryos & As ${ }^{\mathrm{III}}$ & {$[118]$} \\
\hline \multicolumn{4}{|l|}{ Other changes } \\
\hline Amplification of the dihydrofolate reductase gene & Mouse 3T6 cells & $\mathrm{As}^{\mathrm{III}}$ & {$[129]$} \\
\hline $\begin{array}{l}\text { MAPK activation; phosphorylation of ATF- } 2 \text { and c-Jun, } \\
\text { elevated IL- } 8 \text { release }\end{array}$ & Human BEAS 2B line & As $s^{\mathrm{III}}$ & {$[130]$} \\
\hline $\begin{array}{l}\text { Induction of p53-independent expression of GADD45 } \\
\text { protein (a G2/M cell-cycle checkpoint protein) }\end{array}$ & Human BEAS 2B line & $\mathrm{As}^{\mathrm{III}}$ & {$[131]$} \\
\hline Stabilization of GADD45 alpha mRNA through nucleolin & Human BEAS 2B line & $A s^{I I I}$ & {$[132]$} \\
\hline $\begin{array}{l}\text { Mostly decreased expression for transcripts involved in } \\
\text { angiogenesis, lipid metabolism, oxygen transport, apoptosis, } \\
\text { cell cycle, and immune response }\end{array}$ & Lung of mice exposed & $\mathrm{As}^{\mathrm{III}}$ & {$[133]$} \\
\hline
\end{tabular}


Table 1: Continued.

\begin{tabular}{|c|c|c|c|}
\hline Type of alteration & Cell model/type & As species & Reference \\
\hline $\begin{array}{l}\text { Induction of the expression of genes involved with cancer, } \\
\text { the cell cycle, cellular proliferation, DNA replication, } \\
\text { recombination and repair, lipid metabolism, cell-cell } \\
\text { signaling and interaction, molecular transport, and } \\
\text { immunological disease pathways in Ogg } 1^{-/-} \text {mice }\end{array}$ & $\begin{array}{l}\text { Lungs of Ogg } 1^{-/-} \text {mutant mice } \\
\text { exposed }\end{array}$ & $\mathrm{DMA}^{\mathrm{V}}$ & {$[134]$} \\
\hline $\begin{array}{l}\text { Enhanced centrosome amplification in p53-compromised } \\
\text { cells. Resistance to arsenite-induced G2/M cell cycle arrest } \\
\text { and arsenite-induced apoptosis in p53-compromised cells. } \\
\text { Reductions in arsenite-induced enhancement of p53, p } 21 \text {, } \\
\text { and Gadd } 45 \text { a expressions (at } 5-10 \mu \mathrm{M}) \text {, Higher }(200 \%) \text { cell } \\
\text { colony formation in p53-inhibited BEAS-2B cells }(5 \mu \mathrm{M})\end{array}$ & $\begin{array}{l}\text { H1355 cells (human lung } \\
\text { adenocarcinoma cell line with } \\
\text { mutation in p53) Human } \\
\text { BEAS-2B line p53-inhibited } \\
\text { BEAS-2B cells }\end{array}$ & $A s^{I I I}$ & {$[135]$} \\
\hline $\begin{array}{l}\text { Increased expression of ER-alpha and genes related to } \\
\text { estrogen signaling in the fetal lung of female mice }\end{array}$ & $\begin{array}{l}\text { Lung samples from gestation day } \\
18 \text { female fetal } \mathrm{C} 3 \mathrm{H} \text { mice }\end{array}$ & $A s^{I I I}$ & {$[136]$} \\
\hline $\begin{array}{l}\text { Downregulation of (validated genes): Tpi1, Ldha, and Pgk1. } \\
\text { Upregulation of (validated genes): Cox6a2; Variable: Id1, } \\
\text { Gpnmb }\end{array}$ & Rat lung epithelial cell line (L2) & $\mathrm{As}^{\mathrm{III}}$ & {$[137]$} \\
\hline $\begin{array}{l}\text { Increased cell viability }(\leq 0.5 \mu \mathrm{M}) \text {. Downregulation of APE1 } \\
\text { and } \operatorname{Pol} \beta \text { mRNA (above } 1 \mu \mathrm{M})\end{array}$ & $\begin{array}{l}\text { GM847-immortalized human } \\
\text { lung fibroblast }\end{array}$ & $A s^{I I I}$ & {$[138]$} \\
\hline $\begin{array}{l}\text { Increased plating efficiency (cell growth advantage), } \\
\text { micronuclei incidence (marker of chromosomal instability), } \\
\text { gene amplification (PALA resistance), invasive capabilities; } \\
\text { anchorage-independent growth (oncogenic transformation); } \\
\text { lost of } \beta 4 \text { integrin expression; upregulated phosphorylation } \\
\text { of Rb and ERK; decreased expression of p53 protein }\end{array}$ & $\begin{array}{l}\text { h-TERT-immortalized human } \\
\text { small airway epithelial cells }\end{array}$ & $\mathrm{As}^{\mathrm{III}}$ & {$[139]$} \\
\hline
\end{tabular}

methylation activity could predispose individuals to arsenicrelated skin malignancies.

3.2. Arsenic-Induced Oxidative Stress. Cellular induced damage derived from arsenic biotransformation leading to carcinogenic processes have usually been described to occur through oxidative stress by generation of toxic species, such as reactive oxygen species (ROS) leading to genomic aberrations. Generation of ROS has been described as one of the earliest and most important mechanisms of arsenic-induced carcinogenicity [86-91]. Oxidative damage (measured as guanine oxidation) is significantly associated with skin tumors associated with arsenic exposure [92, 93]. It has also been shown that oxidative stress can modify gene transcription profiles of human hyperkeratosis, affecting several cancer-relevant pathways, such as the $\mathrm{Wnt} / \beta$-catenin and calcium signaling pathways [94, 95]. Both single- and double DNA strand breaks are characteristic of most cancer types and have been shown to be induced by chronic arsenic exposure, even at low concentrations $[96,97]$.

3.3. Epigenetic Changes. Arsenic, arsenic metabolites, and metabolism, directly and indirectly, affect normal epigenetic transcriptional regulation at both the level of DNA methylation, histone maintenance, and miRNA expression (reviewed in $[98,99])$. As previously mentioned, biotransformation and reduction of arsenic leads to the formation of highly toxic methylated arsenic species which act as potent cytotoxics and enzyme inhibitors. Since this process utilizes SAM, the cell's own methyl group donor, arsenic is thought to interfere with the cell's ability to maintain normal epigenetic regulation via the disruption of normal DNA methylation patterns, histone modification, and expression of microRNAs (miRNAs), possibly by the depletion of cellular pools of methyl groups (Figure 2). Epigenetic modifications do not alter the DNA sequence itself but instead result in chemical modifications to DNA or histone tail residues. Cells and tissues exposed to arsenic display epigenetic aberrations that mimic early hallmarks of cancer, providing evidence for an epigenetic role in arsenic-mediated tumorigenesis. Epigenetic regulation of gene expression is a highly dynamic process that can be modulated by existing therapeutics $[100,101]$ which may potentially apply to arsenic-related malignancies.

3.3.1. DNA Methylation. In the human genome, DNA methylation occurs at the 5-carbon position of cytosine in $\mathrm{CpG}$ dinucleotide sequences, resulting in $5^{\prime}$-methylcytosine $(5 \mathrm{mC})$, often within short evolutionarily conserved regions enriched for $\mathrm{CpG}$ dinucleotides, called $\mathrm{CpG}$ islands $[102,103]$. When located in promoter regions of genes, CpG islands are typically unmethylated ( 90\%); however, promoters without $\mathrm{CpG}$ islands are frequently methylated [104]. Therefore, the bulk of methylated DNA in the human genome occurs in repetitive DNA sequences, where it is thought to have an important role in silencing transposable elements and maintaining genomic stability. The transfer of the donor methyl group from SAM to the cytosine in a CpG dinucleotides is catalyzed by DNA methyl transferase (DNMT) enzymes, responsible for the de novo methylation 


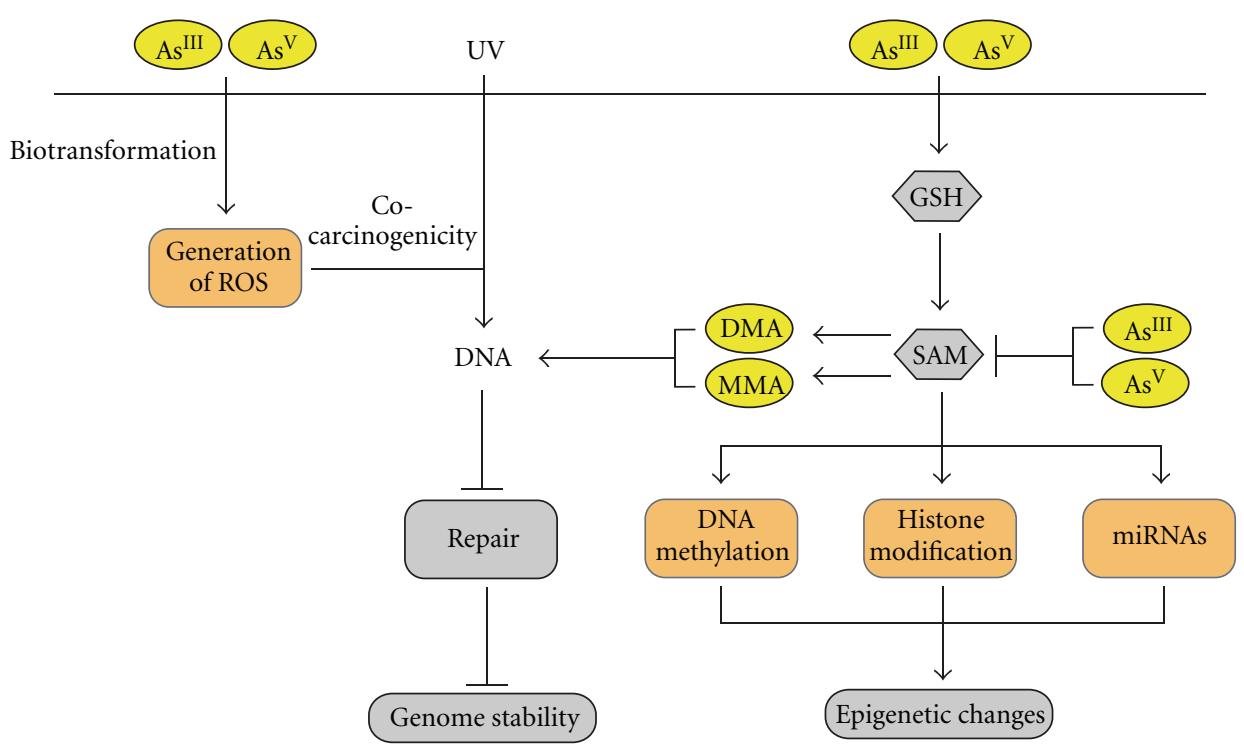

FIGURE 2: Schematic representation of proposed arsenic-induced carcinogenic mechanisms. Arsenic can enter cells in both tri- or pentavalent forms (As $s^{\mathrm{III}}$ or $\mathrm{As} \mathrm{s}^{\mathrm{V}}$ ). Inside cells, $\mathrm{As} \mathrm{s}^{\mathrm{V}}$ is converted to $\mathrm{As}{ }^{\mathrm{III}}$, with subsequent methylation to monomethylated (MMA) and dimethylated (DMA) species. The methylation of inorganic arsenic consumes both S-adenosylmethionine (SAM) and glutathione (GSH). Cellular damage derived from arsenic biotransformation can occur through generation of reactive oxygen species (ROS), and through epigenetic mechanisms: changes in DNA methylation patterns (by depletion of cellular pools of methyl group), histone modification, and altered expression of microRNAs (miRNAs).

throughout development (DNMT3a, DNMT3b, and DNMT3L) and maintenance of methylation patterns in somatic tissue (DNMT1). Aberrant DNA methylation is implicated in a vast spectrum of diseases and disorders and is one of the earliest and most frequent aberrations in cancer. DNA hypomethylation is associated with genomic instability and the reexpression of parasitic DNA, in addition to activation of genes normally silenced by methylation in a tissue-specific manner. Conversely, aberrant DNA promoter hypermethylation is strongly linked to transcriptional gene silencing, particularly for tumor suppressor genes (TSGs) and cancer.

DNA methylation patterns observed in human cancers resemble those of arsenic-related premalignant and malignant cells and tissues. For example, the DNA methylation patterns of several well-known cancer genes have been studied in the context of, and found to correlate with, arsenic exposure in in vitro cell models and in populations exposed to arsenic. The activation of proliferative genes in rat liver epithelial cell lines which undergo malignant transformation following chronic, low-level arsenic exposure is associated with aberrant DNA hypomethylation [105]. Exposure to $A s^{I I I}$ and $A s^{V}$ in the lung cancer cell line (A549), resulted in promoter hypermethylation and subsequent transcriptional silencing of p53 [106]. Mice, chronically exposed to $A s^{V}$ through drinking water, acquire frequent promoter hypermethylation of the tumor suppressors $p 16^{I N K 4 A}$ and RASSF1A in lung tumor tissues [107]. A study analyzing 351 cases of bladder cancer cases found that arsenic exposure was associated with promoter methylation of RASSF1A and PRSS3 [108]. Intriguingly, in one study, individuals with no cancer, but who were exposed to high arsenic concentrations ( $>251 \mu \mathrm{g} / \mathrm{L}$ ), had a significant degree of DNA hypermethylation in promoter regions of $p 53$ and $p 16^{I N K 4 A}$ compared to nonexposed controls [109], suggesting that arsenic related-hypermethylation events may be some of the earliest causal tumorigenic events. Collectively, these and other findings (see $[98,99]$ ) support the notion that arsenicinduced changes to DNA methylation play a role in tumor formation.

3.3.2. Histone Modification. Histones proteins enable condensation of double-stranded supercoiled eukaryotic DNA into nucleosomes, which are made up of two copies each of $\mathrm{H} 2 \mathrm{~A}, \mathrm{H} 2 \mathrm{~B}, \mathrm{H} 3$, and $\mathrm{H} 4$ proteins. The $\mathrm{N}$-terminal tails of histones are accessible to modifying enzymes, which function in catalyzing posttranslational modifications to the amino acid residues residing within the histone tail, including acetylation, methylation, ubiquitination, sumoylation, and phosphorylation amongst others $[110,111]$. Specific patterns of these modifications, commonly referred to as the "histone code", correlate with transcriptional states of associated genes as well as to disease phenotypes. Working in conjunction with transcriptional coactivators or repressors, histone modifying enzymes catalyze the addition or removal of these modifications to generally induce or maintain an (1) open euchromatic state, through the addition of acetyl groups (via histone acetyltransferases) or (2) a closed or heterchromatic state, through the addition of methyl groups (via histone methyltransferases) or removal of acetyl groups (via histone deacetylases) on specific histone residues. Therefore, transcriptional activity of associated genes correlates with the formation of euchromatin or heterochromatin. 
Arsenic metabolites have been shown to modulate normal histone patterns. As ${ }^{\mathrm{III}}$ has also been shown to modify methylation patterns on $\mathrm{H} 3 \mathrm{~K} 4, \mathrm{H} 3 \mathrm{~K} 9$, and $\mathrm{H} 3 \mathrm{~K} 27$ [112]. A549 cells exposed to $2.5-5 \mu \mathrm{M}$ of As ${ }^{\mathrm{III}}$ exhibited an increase in $\mathrm{H} 3 \mathrm{~K} 9$ dimethylation and a decrease in $\mathrm{H} 3 \mathrm{~K} 27$ trimethylation, both of which are associated with heterochromatin (gene silencing), and a decrease in $\mathrm{H} 3 \mathrm{~K} 4$ trimethylation which is associated with euchromatin formation (an activation mark). When the normal bronchial epithelial cell line (BEAS-2B) was exposed to $1-2 \mu \mathrm{M}$ of $\mathrm{As}^{\mathrm{III}}$, an increase in dimethylation of $\mathrm{H} 3 \mathrm{~K} 9$ was observed.

Arsenic compounds were also shown to induce malignant transformation of human nontumorigenic cell lines through changes to histone $\mathrm{H} 3$ acetylation, DNA promoter methylation, and decreases expression of the $D B C 1$, FAM83A, ZSCAN12, and C1QTNF6 genes [113]. For each of these underexpressed genes, DNA methylation inversely correlated with the histone acetylation levels for their respective promoter regions, leading authors to conclude that changes in histone $\mathrm{H} 3$ acetylation occur during arsenicinduced malignant transformation.

3.3.3. MicroRNAs. miRNAs are small, noncoding RNA species that orchestrate the expression of genes involved in many key aspects of cell biology by degradation and translational inhibition of their target mRNAs (reviewed in [114]). In humans, more than 1400 miRNAs have been identified to date (miRBase data base; Release 17, April 2011). miRNAs inhibit gene expression by binding to the $3^{\prime}$-untranslated region of mRNAs through imperfect base pairing; consequently, a single miRNA can negatively regulate the expression of multiple and sometimes upwards of hundreds target genes. As a result, miRNAs deregulations are implicated in diverse human pathologies, including cancer (reviewed in [115]).

An increasing number of studies show that arsenic exposure can alter miRNA expression levels in vitro and in vivo. Human lymphoblastoid cells exposed to sodium As III over six days showed altered expression of five miRNAs (hsa-miR-210, -22, -34a, -221, and -222) [116]. The authors hypothesized that these alterations could be a consequence of changes in methylation patterns, since the same alterations were observed when cells were grown under folate-deficient conditions, which can lead to reduced levels of SAM. Furthermore, overexpression of hsa-miR-222 was confirmed in human peripheral blood-derived cells from individuals with insufficient dietary folate. The induced changes in miRNA expression could be reversed by the restoration of folate, suggesting that continuous exposure to agents like arsenic may be necessary to permanently alter the expression of miRNAs.

Chronic exposure to As ${ }^{\mathrm{III}}$ has also been shown to induce malignant transformation and epithelial-to-mesenchymal transition (EMT), in concert with reduction in levels of miR200 family members in immortalized p53-knocked downhuman bronchial epithelial cells (HBECs) but not in p53intact HBECs [117]. Interestingly, stable expression of miR$200 \mathrm{~b}$ alone was capable of entirely reversing and preventing
$\mathrm{As}^{\mathrm{III}}$-induced EMT and malignant transformation. Arsenic exposure depleted the miR-200s through the induction of EMT-inducing transcription factors zinc-finger E-boxbinding homeobox factor 1 (ZEB1) and ZEB2 and increased methylation of miR-200 promoters.

A recent study examining the global expression of miRNAs and mRNAs of chick embryos after arsenic exposure revealed a dramatic decrease in expression of miRNA-9, $-181 \mathrm{~b},-124$, and -125b [118]. NRP1-a transmembrane receptor involved in angiogenesis-which is upregulated at the mRNA level in arsenic-treated chick embryos was found to be a target gene of miR-9 and miR-181b. Overexpression of miR-9 or miR-181b suppressed As ${ }^{\mathrm{III}}$-induced NRP1 expression, cell migration and tube formation, supporting involvement of these miRNA species in $\mathrm{As}^{\mathrm{III}}$-induced angiogenesis via NRP1 gene activation.

Despite its carcinogenic potential, $\mathrm{As}^{\mathrm{III}}$ has also been used as a treatment option for APL, which is frequently associated with a gene fusion involving the retinoic acid receptor alpha (RARA) and the promyelocytic leukemia protein (PML) gene [119]. Saumet et al. have shown that PML-RARA is able to transcriptionally repress several miRNAs associated with critical pathways linked to leukemogenesis, such as HOX proteins and cell adhesion molecules [120]. Expression of these miRNAs was restored by retinoic acid and As ${ }^{\mathrm{III}}$, suggesting that, in APL, these agents may function to inhibit cell growth, at least in part by impacting miRNA expression.

\section{Conclusion}

Arsenic contamination of drinking water remains a serious public health problem, affecting hundreds of millions individuals worldwide. The more severe effects, such as cancer, are evident up to several decades after exposure has ceased. Although mitigation measures have been taken, the natural origin of this contamination keeps this problem an active preoccupation that requires strategies to monitor arsenic concentrations in drinking water and to define markers associated with early health effects.

Overall, reviewed literature indicates that arsenic exposure exerts deleterious health effects primarily through the induction of oxidative stress, alterations to DNA methylation, histone modification, and miRNA expression. Understanding these events in the context of arsenic toxicity may provide powerful biomarkers for arsenic-induced carcinogenicity and elucidation of early steps in arsenic-induced malignancies that may be reversed by targeted therapies or preventative chemotherapeutics. Larger, carefully designed epidemiologic studies will be required to more comprehensively examine the presence and consequence of these alterations in populations affected by arsenic contamination. Since synergistic cocarcinogenicity, especially in skin and lung cancer, occurs in arsenic-exposed individuals, considerations of other environmental agents should be taken into account in these studies. Elucidation of the mechanisms underlying the initiation and promotion of carcinogenesis related to arsenic's biotransformation processes and metabolites is of foremost importance to the development of early detection and treatment regimes for affected individuals. 


\section{Acknowledgments}

This work was supported by Grants from the Canadian Institutes for Health Research (CIHR) (MOP-86731, MOP-77903, and MOP-110949), Canadian Cancer Society (CCS20485), and INNOVA-CORFO Grants (07CN13PBT48). V. D. Martinez was supported by fellowships from the Government of Canada Awards Programme and the MECESUP-UCH0306 project. E. A. Vucic is supported by a Frederick Banting and Charles Best Canada Graduate Scholarship from CIHR.

\section{References}

[1] M. Vahter, "Mechanisms of arsenic biotransformation," Toxicology, vol. 181-182, pp. 211-217, 2002.

[2] Agency for Toxic Substances and Disease Registry (ATSDR), Toxicological Profile for Arsenic, U.S. Department of Health and Human Services, Washington, DC, USA, 2007.

[3] European Food Safety Authority (EFSA) and EFSA Panel on Contaminants in the Food Chain (CONTAM), "Scientific opinion on arsenic in food," EFSA Journal, vol. 7, no. 10, articel 1351, 199 pages, 2009.

[4] D. N. G. Mazumder, "Diagnosis and treatment of chronic arsenic poisoning," in United Nations Synthesis Report on Arsenic in Drinking Water, WHO, Geneva, Switzerland, 2000.

[5] M. Argos, T. Kalra, P. J. Rathouz et al., "Arsenic exposure from drinking water, and all-cause and chronic-disease mortalities in Bangladesh (HEALS): a prospective cohort study," The Lancet, vol. 376, no. 9737, pp. 252-258, 2010.

[6] D. K. Nordstrom, "Public health. Worldwide occurrences of arsenic in ground water," Science, vol. 296, no. 5576, pp. 2143-2145, 2002.

[7] International Agency for Cancer Research (IARC), "Some drinking-water disinfectants and contaminants, including arsenic," in IARC Monographs on the Evaluation of Carcinogenic Risks to Humans, vol. 84, International Agency for Cancer Research (IARC), Lyon, France, 2004.

[8] A. H. Smith, E. O. Lingas, and M. Rahman, "Contamination of drinking-water by arsenic in Bangladesh: a public health emergency," Bulletin of the World Health Organization, vol. 78, no. 9, pp. 1093-1103, 2000.

[9] I. D. Gregori, E. Fuentes, M. Rojas, H. Pinochet, and M. Potin-Gautier, "Monitoring of copper, arsenic and antimony levels in agricultural soils impacted and non-impacted by mining activities, from three regions in Chile," Journal of Environmental Monitoring, vol. 5, no. 2, pp. 287-295, 2003.

[10] G. Marshall, C. Ferreccio, Y. Yuan et al., "Fifty-Year study of lung and bladder cancer mortality in Chile related to arsenic in drinking water," Journal of the National Cancer Institute, vol. 99, no. 12, pp. 920-928, 2007.

[11] World Health Organization (WHO), WHO Guidelines for Drinking-Water Quality, WHO, Geneva, Switzerland, 1993.

[12] U. S. Environmental Protection Agency (EPA), Technical Fact Sheet: Proposed Rule for Arsenic in Drinking Water, U. S. Environmental Protection Agency (EPA), Washington, DC, USA, 2001.

[13] M. N. Mead, "Arsenic: in search of an antidote to a global poison," Environmental Health Perspectives, vol. 113, no. 6, pp. A378-A386, 2005.

[14] D. Chakraborti, M. M. Rahman, K. Paul et al., "Arsenic calamity in the Indian subcontinent: what lessons have been learned?" Talanta, vol. 58, no. 1, pp. 3-22, 2002.
[15] C. J. Chen, Y. M. Hsueh, M. S. Lai et al., "Increased prevalence of hypertension and long-term arsenic exposure," Hypertension, vol. 25, no. 1, pp. 53-60, 1995.

[16] R. R. Engel, C. Hopenhayn-Rich, O. Receveur, and A. H. Smith, "Vascular effects of chronic arsenic exposure: a review," Epidemiologic Reviews, vol. 16, no. 2, pp. 184-209, 1994.

[17] T. Kadono, T. Inaoka, N. Murayama et al., "Skin manifestations of arsenicosis in two villages in Bangladesh," International Journal of Dermatology, vol. 41, no. 12, pp. 841846, 2002.

[18] W. P. Tseng, "Effects and dose response relationships of skin cancer and blackfoot disease with arsenic," Environmental Health Perspectives, vol. 19, pp. 109-119, 1977.

[19] M. N. Bates, A. H. Smith, and C. Hopenhayn-Rich, "Arsenic ingestion and internal cancers: a review," American Journal of Epidemiology, vol. 135, no. 5, pp. 462-476, 1992.

[20] International Agency for Research on Cancer (IARC), "Some drinking-water disinfectants and contaminants, including arsenic. Monographs on chloramine, chloral and chloral hydrate, dichloroacetic acid, trichloroacetic acid and 3chloro-4-(dichloromethyl)-5-hydroxy-2(5H)-furanone," in IARC Monographs on the Evaluation of Carcinogenic Risks to Humans, vol. 84, pp. 269-477, International Agency for Research on Cancer (IARC), Lyon, France, 2004.

[21] C. J. Chen and C. J. Wang, "Ecological correlation between arsenic level in well water and age-adjusted mortality from malignant neoplasms," Cancer Research, vol. 50, no. 17, pp. 5470-5474, 1990.

[22] A. H. Smith, M. Goycolea, R. Haque, and M. L. Biggs, "Marked increase in bladder and lung cancer mortality in a region of northern Chile due to arsenic in drinking water," American Journal of Epidemiology, vol. 147, no. 7, pp. 660669, 1998.

[23] C. Hopenhayn-Rich, M. L. Biggs, A. Fuchs et al., "Bladder cancer mortality associated with arsenic in drinking water in Argentina," Epidemiology, vol. 7, no. 2, pp. 117-124, 1996.

[24] K. H. Morales, L. Ryan, T. L. Kuo, M. M. Wu, and C. J. Chen, "Risk of internal cancers from arsenic in drinking water," Environmental Health Perspectives, vol. 108, no. 7, pp. 655$661,2000$.

[25] C. Ferreccio, C. González, V. Milosavjlevic, G. Marshall, A. M. Sancha, and A. H. Smith, "Lung cancer and arsenic concentrations in drinking water in Chile," Epidemiology, vol. 11, no. 6, pp. 673-679, 2000.

[26] A. H. Smith, C. Hopenhayn-Rich, M. N. Bates et al., "Cancer risks from arsenic in drinking water," Environmental Health Perspectives, vol. 97, pp. 259-267, 1992.

[27] V. Mathews, B. George, E. Chendamarai et al., "Single-agent arsenic trioxide in the treatment of newly diagnosed acute promyelocytic leukemia: long-term follow-up data," Journal of Clinical Oncology, vol. 28, no. 24, pp. 3866-3871, 2010.

[28] Z. Y. Wang and Z. Chen, "Acute promyelocytic leukemia: from highly fatal to highly curable," Blood, vol. 111, no. 5, pp. 2505-2515, 2008.

[29] V. L. Armando and A. O. Angel, "Chronic arsenic poisoning," Boletin Medico del Hospital Infantil de Mexico, vol. 36, no. 5, pp. 849-861, 1979.

[30] R. Zaldivar, L. Prunes, and G. L. Ghai, "Arsenic dose in patients with cutaneous carcinomata and hepatic haemangio-endothelioma after environmental and occupational exposure," Archives of Toxicology, vol. 47, no. 2, pp. 145-154, 1981. 
[31] J. Cuzick, S. Evans, M. Gillman, and D. A. P. Evans, "Medicinal arsenic and internal malignancies," British Journal of Cancer, vol. 45, no. 6, pp. 904-911, 1982.

[32] H. H. Wong and J. Wang, "Merkel cell carcinoma," Archives of Pathology and Laboratory Medicine, vol. 134, no. 11, pp. 1711-1716, 2010.

[33] W. Boonchai, A. Green, J. Ng, A. Dicker, and G. ChenevixTrench, "Basal cell carcinoma in chronic arsenicism occurring in Queensland, Australia, after ingestion of an asthma medication," Journal of the American Academy of Dermatology, vol. 43, no. 4, pp. 664-669, 2000.

[34] H. C. Lien, T. F. Tsai, Y. Y. Lee, and C. H. Hsiao, "Merkel cell carcinoma and chronic arsenicism," Journal of the American Academy of Dermatology, vol. 41, no. 4, pp. 641-643, 1999.

[35] S. S. Wong, K. C. Tan, and C. L. Goh, "Cutaneous manifestations of chronic arsenicism: review of seventeen cases," Journal of the American Academy of Dermatology, vol. 38, no. 2 I, pp. 179-185, 1998.

[36] K. Castren, A. Ranki, J. A. Welsh, and K. H. Vähäkangas, "Infrequent p53 mutations in arsenic-related skin lesions," Oncology Research, vol. 10, no. 9, pp. 475-482, 1998.

[37] C. H. Lee, C. L. Yu, W. T. Liao et al., "Effects and interactions of low doses of arsenic and UVB on keratinocyte apoptosis," Chemical Research in Toxicology, vol. 17, no. 9, pp. 11991205, 2004.

[38] H. S. Yu, C. H. Lee, S. H. Jee, C. K. Ho, and Y. L. Guo, "Environmental and occupational skin diseases in Taiwan," Journal of Dermatology, vol. 28, no. 11, pp. 628-631, 2001.

[39] T. Yoshida, H. Yamauchi, and G. F. Sun, "Chronic health effects in people exposed to arsenic via the drinking water: dose-response relationships in review," Toxicology and Applied Pharmacology, vol. 198, no. 3, pp. 243-252, 2004.

[40] R. Haque, D. N. G. Mazumder, S. Samanta et al., "Arsenic in drinking water and skin lesions: dose-response data from West Bengal, India," Epidemiology, vol. 14, no. 2, pp. 174-182, 2003.

[41] H. R. Guo, H. S. Yu, H. Hu, and R. R. Monson, "Arsenic in drinking water and skin cancers: cell-type specificity (Taiwan, ROC)," Cancer Causes and Control, vol. 12, no. 10, pp. 909-916, 2001.

[42] K. A. Bailey, S. D. Hester, G. W. Knapp, R. D. Owen, and S. F. Thai, "Gene expression of normal human epidermal keratinocytes modulated by trivalent arsenicals," Molecular Carcinogenesis, vol. 49, no. 12, pp. 981-998, 2010.

[43] S. Melkonian, M. Argos, B. L. Pierce et al., "A prospective study of the synergistic effects of arsenic exposure and smoking, sun exposure, fertilizer use, and pesticide use on risk of premalignant skin lesions in Bangladeshi men," American Journal of Epidemiology, vol. 173, no. 2, pp. 183191, 2011.

[44] D. Caussy, Ed., A Field Guide for Detection, Management, and Surveillance of Arsenicosis Cases, World Health Organization, Regional Office of South-East Asia, New Delhi, India, 2005.

[45] T. G. Rossman, A. N. Uddin, and F. J. Burns, "Evidence that arsenite acts as a cocarcinogen in skin cancer," Toxicology and Applied Pharmacology, vol. 198, no. 3, pp. 394-404, 2004.

[46] Agency for Toxic Substances and Disease Registry (ATSDR), Arsenic Toxicity, U.S. Department of Health and Human Services, Washington DC, USA.

[47] K. C. Saha, "Diagnosis of arsenicosis," Journal of Environmental Science and Health Part A, vol. 38, no. 1, pp. 255-272, 2003.

[48] IARC, "Some Metals and Metallic Compounds," in IARC Monographs on the Evaluation of Carcinogenic Risks to
Humans, vol. 20, pp. 39-141, International Agency for Research on Cancer, Lyon, France, 1980.

[49] H. Danaee, H. H. Nelson, H. Liber, J. B. Little, and K. T. Kelsey, "Low dose exposure to sodium arsenite synergistically interacts with UV radiation to induce mutations and alter DNA repair in human cells," Mutagenesis, vol. 19, no. 2, pp. 143-148, 2004.

[50] S. De Chaudhuri, M. Kundu, M. Banerjee et al., "Arsenicinduced health effects and genetic damage in keratotic individuals: involvement of p53 arginine variant and chromosomal aberrations in arsenic susceptibility," Mutation Research, vol. 659, no. 1-2, pp. 118-125, 2008.

[51] Y. Chen, J. H. Graziano, F. Parvez et al., "Modification of risk of arsenic-induced skin lesions by sunlight exposure, smoking, and occupational exposures in Bangladesh," Epidemiology, vol. 17, no. 4, pp. 459-467, 2006.

[52] M. M. Wu, T. L. Kuo, Y. H. Hwang, and C. J. Chen, "Doseresponse relation between arsenic concentration in well water and mortality from cancers and vascular diseases," American Journal of Epidemiology, vol. 130, no. 6, pp. 1123-1132, 1989.

[53] S. C. Sommers and R. G. McManus, "Multiple arsenical cancers of skin and internal organs," Cancer, vol. 6, no. 2, pp. 347-359, 1953.

[54] A. W. Williamson, "Arsenical skin cancer and lung cancer. A report of two cases," Guy's Hospital Reports, vol. 109, pp. 4245, 1960.

[55] A. O. Robson and A. M. Jelliffe, "Medicinal arsenic poisoning and lung cancer," British Medical Journal, vol. 2, no. 5351, pp. 207-209, 1963.

[56] I. Celik, L. Gallicchio, K. Boyd et al., "Arsenic in drinking water and lung cancer: a systematic review," Environmental Research, vol. 108, no. 1, pp. 48-55, 2008.

[57] H. Gibb, C. Haver, D. Gaylor et al., "Utility of recent studies to assess the National Research Council 2001 estimates of cancer risk from ingested arsenic," Environmental Health Perspectives, vol. 119, no. 3, pp. 284-290, 2011.

[58] NRC (National Research Council), Arsenic in Drinking Water, National Academy Press, Washington, DC, USA, 1999.

[59] S. M. Tsai, T. N. Wang, and Y. C. Ko, "Mortality for certain diseases in areas with high levels of arsenic in drinking water," Archives of Environmental Health, vol. 54, no. 3, pp. 186-193, 1999.

[60] National Research Council (NRC), Arsenic in Drinking Water-2001 Update, National Academy Press, Washington, DC, USA, 2001.

[61] Servicio de Salud Antofagasta (Unidad de Registro de Cancer), in Proceedings of the III Anuario Registro Regional de Cancer Segunda Region Chile 2000 (Incluye Informacion 1998-2000), Ministerio de Salud, Ed., Antofagasta, Chile, 2000.

[62] M. G. Mostafa, J. C. McDonald, and N. M. Cherry, "Lung cancer and exposure to arsenic in rural Bangladesh," Occupational and Environmental Medicine, vol. 65, no. 11, pp. 765$768,2008$.

[63] C. L. Chen, L. I. Hsu, H. Y. Chiou et al., "Ingested arsenic, cigarette smoking, and lung cancer risk: a follow-up study in arseniasis-endemic areas in Taiwan," Journal of the American Medical Association, vol. 292, no. 24, pp. 2984-2990, 2004.

[64] C. J. Chen, Y. C. Chuang, and S. L. You, "A retrospective study on malignant neoplasms of bladder, lung and liver in blackfoot disease endemic area in Taiwan," British Journal of Cancer, vol. 53, no. 3, pp. 399-405, 1986.

[65] H. Y. Chiou, Y. M. Hsueh, K. F. Liaw et al., "Incidence of internal cancers and ingested inorganic arsenic: a seven- year 
follow-up study in Taiwan," Cancer Research, vol. 55, no. 6, pp. 1296-1300, 1995.

[66] T. Tsuda, A. Babazono, E. Yamamoto et al., "Ingested arsenic and internal cancer: a historical cohort study followed for 33 years," American Journal of Epidemiology, vol. 141, no. 3, pp. 198-209, 1995.

[67] C. Hopenhayn-Rich, M. L. Biggs, and A. H. Smith, "Lung and kidney cancer mortality associated with arsenic in drinking water in Cordoba, Argentina," International Journal of Epidemiology, vol. 27, no. 4, pp. 561-569, 1998.

[68] H.B. Nicolli, T. E. O'Connor, and J. M. Suriano, "Geoquimica del arsenico y de otros oligoelementos en aguas subterraneas de la llanura Sudoriental de la provinda de Cordoba," Miscelanea, vol. 71, pp. 1-112, 1985.

[69] R. Baastrup, M. Sørensen, T. Balstrøm et al., "Arsenic in drinking-water and risk for cancer in Denmark," Environmental Health Perspectives, vol. 116, no. 2, pp. 231-237, 2008.

[70] J. P. Buchet and D. Lison, "Mortality by cancer in groups of the Belgian population with a moderately increased intake of arsenic," International Archives of Occupational and Environmental Health, vol. 71, no. 2, pp. 125-130, 1998.

[71] M. Adonis, V. Martínez, P. Marín, D. Berrios, and L. Gil, "Smoking habit and genetic factors associated with lung cancer in a population highly exposed to arsenic," Toxicology Letters, vol. 159, no. 1, pp. 32-37, 2005.

[72] M. Adonis, V. Martínez, P. Marín, and L. Gil, "CYP1A1 and GSTM1 genetic polymorphisms in lung cancer populations exposed to arsenic in drinking water," Xenobiotica, vol. 35, no. 5, pp. 519-530, 2005.

[73] S. K. Watson, R. J. deLeeuw, D. E. Horsman, J. A. Squire, and W. L. Lam, "Cytogenetically balanced translocations are associated with focal copy number alterations," Human Genetics, vol. 120, no. 6, pp. 795-805, 2007.

[74] V. D. Martinez, T. P. H. Buys, M. Adonis et al., "Arsenicrelated DNA copy-number alterations in lung squamous cell carcinomas," British Journal of Cancer, vol. 103, no. 8, pp. 1277-1283, 2010.

[75] W. R. Cullen, B. C. McBride, and J. Reglinski, "The reaction of methylarsenicals with thiols: some biological implications," Journal of Inorganic Biochemistry, vol. 21, no. 3, pp. 179-194, 1984.

[76] M. Styblo, Z. Drobna, I Jaspers, S. Lin, and D. J. Thomas, "The role of biomethyl-ation in toxicity and carcinogenicity of arsenic: a research update," Environmental Health Perspectives, vol. 110, pp. 767-771, 2002.

[77] D. J. Thomas, M. Styblo, and S. Lin, "The cellular metabolism and systemic toxicity of arsenic," Toxicology and Applied Pharmacology, vol. 176, no. 2, pp. 127-144, 2001.

[78] P. P. Simeonova and M. I. Luster, "Mechanisms of arsenic carcinogenicity: genetic or epigenetic mechanisms?" Journal of Environmental Pathology, Toxicology and Oncology, vol. 19, no. 3, pp. 281-286, 2000.

[79] S. Lin, Q. Shi, F. B. Nix et al., "A novel S-adenosylL-methionine:arsenic(III) methyltransferase from rat liver cytosol," Journal of Biological Chemistry, vol. 277, no. 13, pp. 10795-10803, 2002.

[80] L. Vega, M. Styblo, R. Patterson, W. Cullen, C. Wang, and D. Germolec, "Differential effects of trivalent and pentavalent arsenicals on cell proliferation and cytokine secretion in normal human epidermal keratinocytes," Toxicology and Applied Pharmacology, vol. 172, no. 3, pp. 225-232, 2001.

[81] K. P. Cantor, "Drinking water and cancer," Cancer Causes and Control, vol. 8, no. 3, pp. 292-308, 1997.
[82] Y. M. Hsueh, Y. F. Ko, Y. K. Huang et al., "Determinants of inorganic arsenic methylation capability among residents of the Lanyang Basin, Taiwan: arsenic and selenium exposure and alcohol consumption," Toxicology Letters, vol. 137, no. 12, pp. 49-63, 2003.

[83] R. C. Yu, K. H. Hsu, C. J. Chen, and J. R. Froines, "Arsenic methylation capacity and skin cancer," Cancer Epidemiology Biomarkers and Prevention, vol. 9, no. 11, pp. 1259-1262, 2000.

[84] Y. M. Hsueh, H. Y. Chiou, Y. L. Huang et al., "Serum betacarotene level, arsenic methylation capability, and incidence of skin cancer," Cancer Epidemiology Biomarkers and Prevention, vol. 6, no. 8, pp. 589-596, 1997.

[85] L. M. Del Razo, G. G. García-Vargas, H. Vargas et al., "Altered profile of urinary arsenic metabolites in adults with chronic arsenicism. A pilot study," Archives of Toxicology, vol. 71, no. 4, pp. 211-217, 1997.

[86] M. Kessel, S. X. Liu, A. Xu, R. Santella, and T. K. Hei, "Arsenic induces oxidative DNA damage in mammalian cells," Molecular and Cellular Biochemistry, vol. 234-235, no. 1-2, pp. 301-308, 2002.

[87] K. T. Kitchin and S. Ahmad, "Oxidative stress as a possible mode of action for arsenic carcinogenesis," Toxicology Letters, vol. 137, no. 1-2, pp. 3-13, 2003.

[88] H. Shi, X. Shi, and K. J. Liu, "Oxidative mechanism of arsenic toxicity and carcinogenesis," Molecular and Cellular Biochemistry, vol. 255, no. 1-2, pp. 67-78, 2004.

[89] R. C. Lantz and A. M. Hays, "Role of oxidative stress in arsenic-induced toxicity," Drug Metabolism Reviews, vol. 38, no. 4, pp. 791-804, 2006.

[90] M. Valko, C. J. Rhodes, J. Moncol, M. Izakovic, and M. Mazur, "Free radicals, metals and antioxidants in oxidative stress-induced cancer," Chemico-Biological Interactions, vol. 160, no. 1, pp. 1-40, 2006.

[91] K. T. Kitchin, "Recent advances in arsenic carcinogenesis: modes of action, animal model systems, and methylated arsenic metabolites," Toxicology and Applied Pharmacology, vol. 172, no. 3, pp. 249-261, 2001.

[92] Y. An, Z. Gao, Z. Wang et al., "Immunohistochemical analysis of oxidative DNA damage in arsenic-related human skin samples from arsenic-contaminated area of China," Cancer Letters, vol. 214, no. 1, pp. 11-18, 2004.

[93] M. Matsui, C. Nishigori, S. Toyokuni et al., "The role of oxidative DNA damage in human arsenic carcinogenesis: Detection of 8-hydroxy-2'-deoxyguanosine in arsenic-related Bowen's disease," Journal of Investigative Dermatology, vol. 113, no. 1, pp. 26-31, 1999.

[94] C. Hidalgo and P. Donoso, "Crosstalk between calcium and redox signaling: from molecular mechanisms to health implications," Antioxidants and Redox Signaling, vol. 10, no. 7, pp. 1275-1312, 2008.

[95] H. C. Korswagen, "Regulation of the Wnt/beta-catenin pathway by redox signaling," Developmental Cell, vol. 10, no. 6, pp. 687-688, 2006.

[96] S. Ying, K. Myers, S. Bottomley, T. Helleday, and H. E. Bryant, "BRCA2-dependent homologous recombination is required for repair of Arsenite-induced replication lesions in mammalian cells," Nucleic Acids Research, vol. 37, no. 15, pp. 5105-5113, 2009.

[97] A. D. Kligerman, S. I. Malik, and J. A. Campbell, "Cytogenetic insights into DNA damage and repair of lesions induced by a monomethylated trivalent arsenical," Mutation Research, vol. 695, no. 1-2, pp. 2-8, 2010. 
[98] X. Ren, C. M. McHale, C. F. Skibola, A. H. Smith, M. T. Smith, and L. Zhang, "An emerging role for epigenetic dysregulation in arsenic toxicity and carcinogenesis," Environmental Health Perspectives, vol. 119, no. 1, pp. 11-19, 2011.

[99] J. F. Reichard and A. Puga, "Effects of arsenic exposure on DNA methylation and epigenetic gene regulation," Epigenomics, vol. 2, no. 1, pp. 87-104, 2010.

[100] I. Kurtze, J. Sonnemann, and J. F. Beck, "KRAS-mutated non-small cell lung cancer cells are responsive to either cotreatment with erlotinib or gefitinib and histone deacetylase inhibitors or single treatment with lapatinib," Oncology Reports, vol. 25, no. 4, pp. 1021-1029, 2011.

[101] W. Brazelle, J. M. Kreahling, J. Gemmer et al., "Histone deacetylase inhibitors downregulate checkpoint kinase 1 expression to induce cell death in non-small cell lung cancer cells," PLoS One, vol. 5, no. 12, Article ID e14335, 2010.

[102] R. J. Klose and A. P. Bird, "Genomic DNA methylation: the mark and its mediators," Trends in Biochemical Sciences, vol. 31, no. 2, pp. 89-97, 2006.

[103] E. Li, "Chromatin modification and epigenetic reprogramming in mammalian development," Nature Reviews Genetics, vol. 3, no. 9, pp. 662-673, 2002.

[104] M. Weber, I. Hellmann, M. B. Stadler et al., "Distribution, silencing potential and evolutionary impact of promoter DNA methylation in the human genome," Nature Genetics, vol. 39, no. 4, pp. 457-466, 2007.

[105] C. Q. Zhao, M. R. Young, B. A. Diwan, T. P. Coogan, and M. P. Waalkes, "Association of arsenic-induced malignant transformation with DNA hypomethylation and aberrant gene expression," Proceedings of the National Academy of Sciences of the United States of America, vol. 94, no. 20, pp. 10907-10912, 1997.

[106] M. J. Mass and L. Wang, "Arsenic alters cytosine methylation patterns of the promoter of the tumor suppressor gene p53 in human lung cells: a model for a mechanism of carcinogenesis," Mutation Research, vol. 386, no. 3, pp. 263277, 1997.

[107] X. Cui, T. Wakai, Y. Shirai, K. Hatakeyama, and S. Hirano, "Chronic oral exposure to inorganic arsenate interferes with methylation status of p16INK4a and RASSF1A and induces lung cancer in A/J mice," Toxicological Sciences, vol. 91, no. 2, pp. 372-381, 2006.

[108] C. J. Marsit, M. R. Karagas, A. Schned, and K. T. Kelsey, "Carcinogen exposure and epigenetic silencing in bladder cancer," Annals of the New York Academy of Sciences, vol. 1076, pp. 810-821, 2006.

[109] S. Chanda, U. B. Dasgupta, D. Guhamazumder et al., "DNA hypermethylation of promoter of gene p53 and p16 in arsenic-exposed people with and without malignancy," Toxicological Sciences, vol. 89, no. 2, pp. 431-437, 2006.

[110] C. L. Peterson and M.-A. Laniel, "Histones and histone modifications," Current Biology, vol. 14, no. 14, pp. R546R551, 2004.

[111] T. Kouzarides, "Chromatin modifications and their function,” Cell, vol. 128, no. 4, pp. 693-705, 2007.

[112] X. Zhou, H. Sun, T. P. Ellen, H. Chen, and M. Costa, "Arsenite alters global histone H3 methylation," Carcinogenesis, vol. 29, no. 9, pp. 1831-1836, 2008.

[113] T. J. Jensen, P. Novak, K. E. Eblin, J. A. Gandolfi, and B. W. Futscher, "Epigenetic remodeling during arsenical-induced malignant transformation," Carcinogenesis, vol. 29, no. 8, pp. 1500-1508, 2008.
[114] W. Filipowicz, S. N. Bhattacharyya, and N. Sonenberg, "Mechanisms of post-transcriptional regulation by microRNAs: are the answers in sight?" Nature Reviews Genetics, vol. 9, no. 2, pp. 102-114, 2008.

[115] G. A. Calin and C. M. Croce, "MicroRNA signatures in human cancers," Nature Reviews Cancer, vol. 6, no. 11, pp. 857-866, 2006.

[116] C. J. Marsit, K. Eddy, and K. T. Kelsey, "MicroRNA responses to cellular stress," Cancer Research, vol. 66, no. 22, pp. 1084310848, 2006.

[117] Z. Wang, Y. Zhao, and E. Smith, "Reversal and prevention of arsenic-induced human bronchial epithelial cell malignant transformation by microRNA-200b," Toxicological Sciences, vol. 121, no. 1, Article ID 10.1093/toxsci/kfr029, pp. 110-122, 2011.

[118] Y. Cui, Z. Han, H. Yi et al., "MicroRNA-181b and microRNA9 mediate arsenic-induced angiogenesis via NRP1," Journal of Cellular Physiology. In press.

[119] G. B. Zhou, W. L. Zhao, Z. Y. Wang, S. J. Chen, and Z. Chen, "Retinoic acid and arsenic for treating acute promyelocytic leukemia," PLoS Medicine, vol. 2, no. 1, article e12, 2005.

[120] A. Saumet, G. Vetter, M. Bouttier et al., "Transcriptional repression of microRNA genes by PML-RARA increases expression of key cancer proteins in acute promyelocytic leukemia," Blood, vol. 113, no. 2, pp. 412-421, 2009.

[121] J. T. Dong and X. M. Luo, "Arsenic-induced DNA-strand breaks associated with DNA-protein crosslinks in human fetal lung fibroblasts," Mutation Research, vol. 302, no. 2, pp. 97-102, 1993.

[122] K. Yamanaka, H. Hayashi, M. Tachikawa et al., "Metabolic methylation is a possible genotoxicity-enhancing process of inorganic arsenics," Mutation Research, vol. 394, no. 1-3, pp. 95-101, 1997.

[123] S. A. Mouron, C. A. Grillo, F. N. Dulout, and C. D. Golijow, "Induction of DNA strand breaks, DNA-protein crosslinks and sister chromatid exchanges by arsenite in a human lung cell line," Toxicology in Vitro, vol. 20, no. 3, pp. 279-285, 2006.

[124] K. Yamanaka, H. Hayashi, K. Kato, A. Hasegawa, and S. Okada, "Involvement of preferential formation of apurinic/apyrimidinic sites in dimethylarsenic-induced DNA strand breaks and DNA-protein crosslinks in cultured alveolar epithelial cells," Biochemical and Biophysical Research Communications, vol. 207, no. 1, pp. 244-249, 1995.

[125] R. Ruiz-Ramos, L. Lopez-Carrillo, A. D. Rios-Perez, A. De Vizcaya-Ruíz, and M. E. Cebrian, "Sodium arsenite induces ROS generation, DNA oxidative damage, $\mathrm{HO}-1$ and c-Myc proteins, NF-kappaB activation and cell proliferation in human breast cancer MCF-7 cells," Mutation Research, vol. 674, no. 1-2, pp. 109-115, 2009.

[126] K. Yamanaka, K. Katsumata, K. Ikuma, A. Hasegawa, M. Nakano, and S. Okada, "The role of orally administered dimethylarsinic acid, a main metabolite of inorganic arsenics, in the promotion and progression of UVB-induced skin tumorigenesis in hairless mice," Cancer Letters, vol. 152, no. 1, pp. 79-85, 2000.

[127] K. Yamanaka, M. Mizoi, K. Kato, A. Hasegawa, M. Nakano, and S. Okada, "Oral administration of dimethylarsinic acid, a main metabolite of inorganic arsenic, in mice promotes skin tumorigenesis initiated by dimethylbenz(a)anthracene with or without ultraviolet B as a promoter," Biological and Pharmaceutical Bulletin, vol. 24, no. 5, pp. 510-514, 2001.

[128] Y. An, K. Kato, M. Nakano, H. Otsu, S. Okada, and K. Yamanaka, "Specific induction of oxidative stress in terminal bronchiolar Clara cells during dimethylarsenic-induced lung 
tumor promoting process in mice," Cancer Letters, vol. 230, no. 1, pp. 57-64, 2005.

[129] F. W. Alt, R. E. Kellems, J. R. Bertino, and R. T. Schimke, "Selective multiplication of dihydrofolate reductase genes in methotrexate-resistant variants of cultured murine cells," Journal of Biological Chemistry, vol. 253, no. 5, pp. 13571370, 1978.

[130] J. M. Samet, L. M. Graves, J. Quay et al., "Activation of MAPKs in human bronchial epithelial cells exposed to metals," American Journal of Physiology, vol. 275, no. 3, pp. L551-L558, 1998.

[131] F. Chen, Y. Lu, Z. Zhang et al., "Opposite effect of NF-kappa B and c-Jun N-terminal kinase on p53-independent GADD45 induction by arsenite," Journal of Biological Chemistry, vol. 276, no. 14, pp. 11414-11419, 2001.

[132] Y. Zhang, D. Bhatia, H. Xia, V. Castranova, X. Shi, and F. Chen, "Nucleolin links to arsenic-induced stabilization of GADD45 \{alpha\} mRNA," Nucleic Acids Research, vol. 34, no. 2, pp. 485-495, 2006.

[133] A. S. Andrew, V. Bernardo, L. A. Warnke et al., "Exposure to arsenic at levels found in U.S. drinking water modifies expression in the mouse lung," Toxicological Sciences, vol. 100, no. 1, pp. 75-87, 2007.

[134] A. Kinoshita, H. Wanibuchi, K. Morimura et al., "Carcinogenicity of dimethylarsinic acid in Ogg1-deficient mice," Cancer Science, vol. 98, no. 6, pp. 803-814, 2007.

[135] W. T. Liao, P. Lin, T. S. Cheng, H. S. Yu, and L. W. Chang, "Arsenic promotes centrosome abnormalities and cell colony formation in p53 compromised human lung cells," Toxicology and Applied Pharmacology, vol. 225, no. 2, pp. 162-170, 2007.

[136] J. Shen, J. Liu, Y. Xie, B. A. Diwan, and M. P. Waalkes, "Fetal onset of aberrant gene expression relevant to pulmonary carcinogenesis in lung adenocarcinoma development induced by in utero arsenic exposure," Toxicological Sciences, vol. 95, no. 2, pp. 313-320, 2007.

[137] T. Posey, T. Weng, Z. Chen et al., "Arsenic-induced changes in the gene expression of lung epithelial L2 cells: implications in carcinogenesis," BMC Genomics, vol. 9, article 115, 2008.

[138] P. Sykora and E. T. Snow, "Modulation of DNA polymerase beta-dependent base excision repair in cultured human cells after low dose exposure to arsenite," Toxicology and Applied Pharmacology, vol. 228, no. 3, pp. 385-394, 2008.

[139] G. Wen, G. M. Calaf, M. A. Partridge et al., "Neoplastic transformation of human small airway epithelial cells induced by arsenic," Molecular Medicine, vol. 14, no. 1-2, pp. 2-10, 2008. 

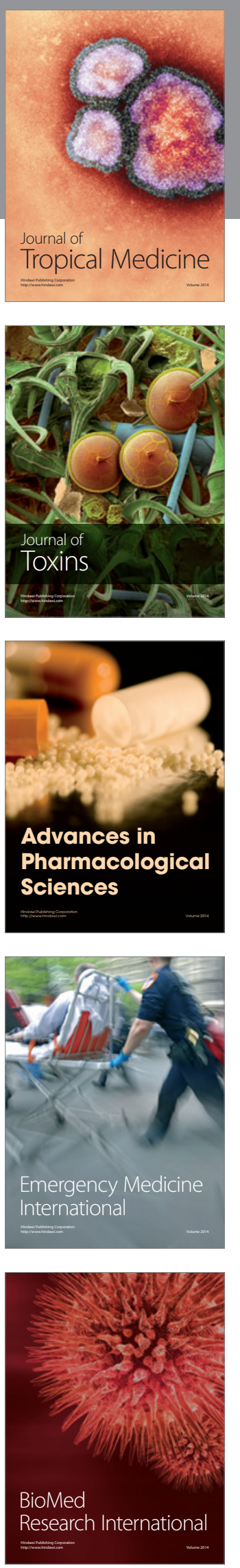
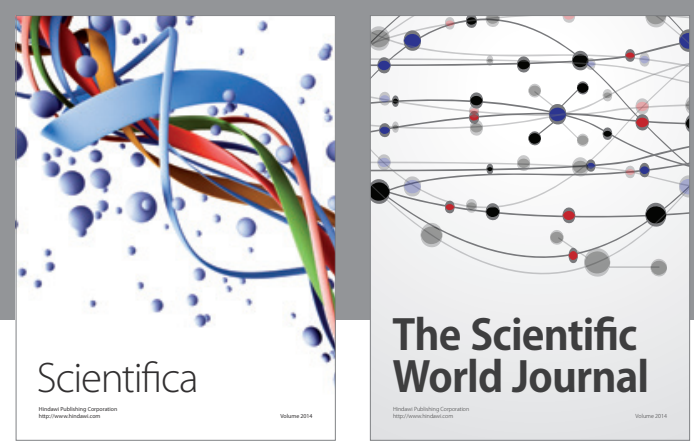

The Scientific World Journal
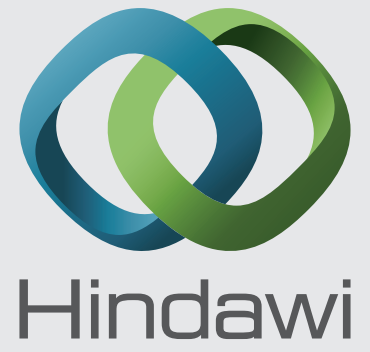

Submit your manuscripts at

http://www.hindawi.com
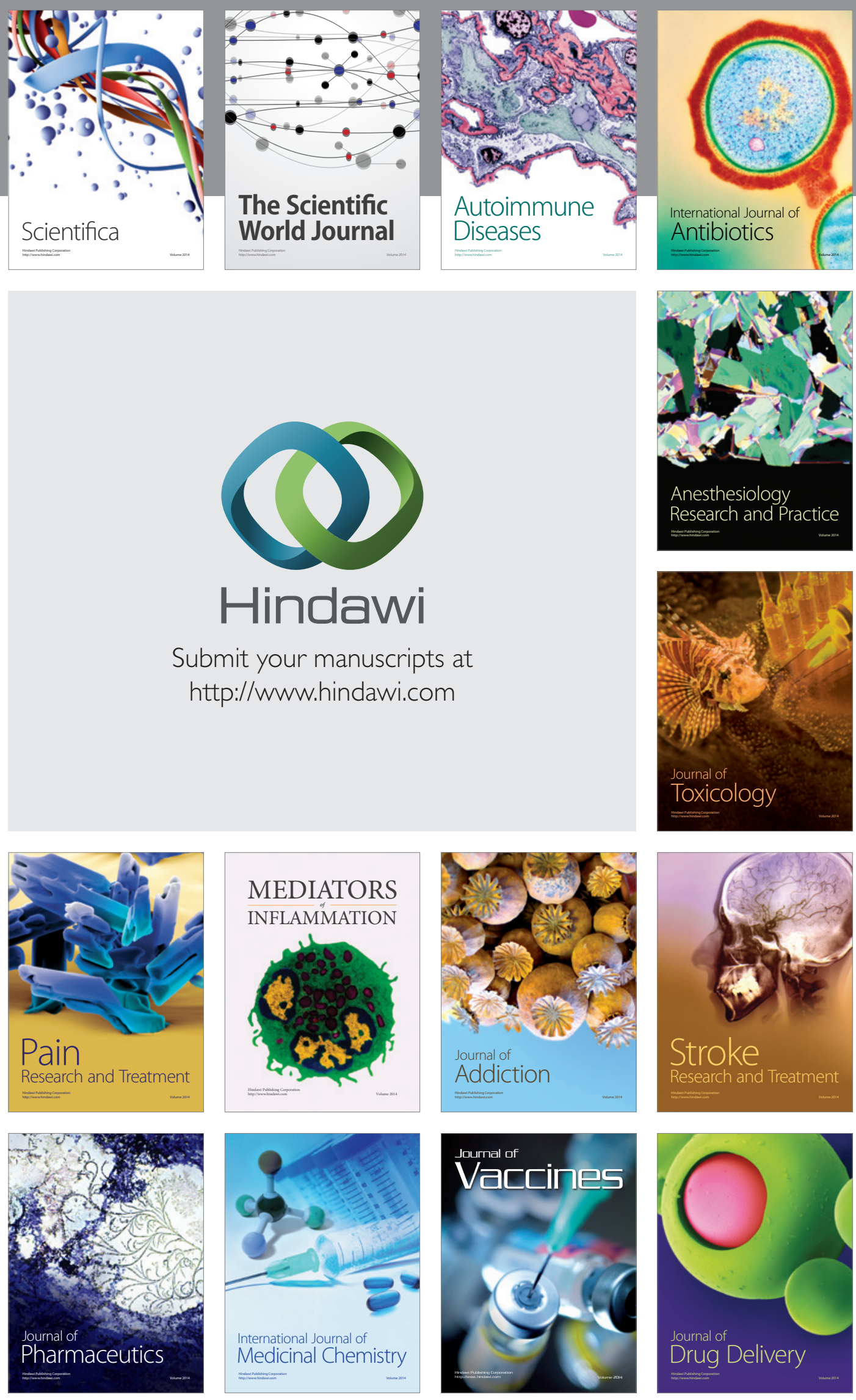